\title{
Home range and population density of black rats (Rattus rattus) on a seabird island: a case for a marine subsidised effect?
}

\author{
Grant A. Harper ${ }^{1, *}$ and Malcolm Rutherford ${ }^{2}$ \\ ${ }^{1}$ Biodiversity Restoration Specialists Ltd, PO Box 65, Murchison 7049, New Zealand \\ ${ }^{2} 388$ Clifford St, Mangapapa, Gisborne, New Zealand \\ *Author for Correspondence (Email: biodivrestoration@gmail.com)
}

Published online: 12 January 2016

\begin{abstract}
Rodents on islands are known to exhibit differing spatial ecology than is seen in mainland habitats and in the case of invasive rats this may affect their impacts on native species. Ship rats' (Rattus rattus) home range size and population densities were measured on Big South Cape Island/Taukihepa, an island with a dense seabird colony, near South-west Stewart Island. Home ranges for both male and female rats were much smaller than had been recorded for virtually all sites in New Zealand. Female home ranges remained at 0.06 ha through a breeding season whereas male home ranges increased in size and also overlapped with more males later in the season. Ship rat population density ranged from $6.5 \mathrm{ha}^{-1}$ in December to $36.4 \mathrm{ha}^{-1}$ by late summer and remained high through autumn. The peaks in measured population densities are among the highest recorded in New Zealand. High populations densities, small home ranges and heavy mean body weights are suggested to be due to high primary productivity attributable to the dense seabird population rather than because of the 'island syndrome'. Further comparisons with other New Zealand islands and mainland sites did not clearly support nor negate the 'island syndrome' in ship rats in New Zealand, although large increases in population densities on Big South Cape Island/Taukihepa did not influence home range sizes.
\end{abstract}

Key words: seabirds, invasive species, island syndrome, reproductive success, body size

\section{Introduction}

Introductions of ship rats (Rattus rattus) to islands have caused declines of many plant and animal species worldwide (Atkinson 1978; Jones et al. 2008). Losses of biodiversity have been most severe on islands, where endemic species are often predatornaïve (Courchamp et al. 2003). The invasion and subsequent irruption of ship rats on Big South Cape Island/ Taukihepa in 1963 led to the extinction of two endemic birds, a bat species, a large weevil and the local extinction of an additional four bird species (Bell 1978; Ramsay 1978; Bell et al. 2016).

Research on invasive rats is increasingly being conducted on seabird islands worldwide due to their importance as biodiversity refuges and the threats posed by rats (Jones et al. 2008), as rats cause cascades of effects through these ecosystems in addition to seabird predation (Fukami et al. 2006; Wardle et al. 2007; Mulder et al. 2009; Towns et al. 2009). However, there has been relatively little research on the population biology of ship rats on seabird islands, with most research being carried out in mainland forest habitats on the very large North, South and Stewart Islands (Daniel 1972; Dowding \& Murphy 1994; Innes et al. 2001; Harper et al. 2005). Although this is surprising considering the large number of seabird islands in New Zealand, the successful number of rat eradications on these islands has now limited the opportunities for conducting research on seabird-rat interactions, which can inform management responses for ship rat control on these islands.

As the population ecology of island rodents may differ from that of continental populations (Gliwicz 1980; Adler \& Levins 1994; Polis et al. 1997) understanding the responses of rats to island ecosystems will assist with their management. There is evidence for increased population densities, larger body sizes and reduced reproductive rates in rodents on islands (Key et al. 1998; Innes 2005), which have been attributed to the 'island syndrome' (Adler \& Levins 1994; Russell et al. 2011 b) as a response to reduced dispersal, competition and predation. Although this effect is recognised, marine subsidies from dense aggregations of seabirds are also known to lead to increased population densities and other changes in population parameters in various animals including rodents (Stapp \& Polis 2003; Mulder et al. 2011; Ruffino et al. 2013), which may be a confounding factor. Certainly on Big South Cape Island/Taukihepa, ship rats exhibited elevated stable nitrogen isotope levels reflecting a high marine input in their diet, but this appeared to be largely due to bottom-up nutrient enrichment across the trophic chain via guano deposition, as little seabird predation was recorded (Harper 2007).

The purpose of this research was to measure the density and home range size of ship rats on a New Zealand island with a dense population of large burrowing seabirds, and compare them with spatial and population data on ship rats on other New Zealand islands without seabirds, competitors or mammalian predators, and from 'mainland' New Zealand. The 'island syndrome' was expected to result in, inter alia, increased population densities, larger body sizes and heavier body mass along with reduced reproductive output on islands compared with populations on the very large islands of the New Zealand 'mainland'. Home range size can be affected by individual energy requirements which are determined by food availability (Harestad \& Bunnell 1979) or by conspecific interactions (Russell et al. 2010). Therefore minimum home range size will contract in more productive habitats due to sufficient resources being available to an individual in a smaller foraging range (McNab 1963) and/or increased territorial encounters with conspecifics. Therefore the rats on the seabird 
island, Big South Cape Island/Taukihepa, were expected to have smaller home ranges, higher population densities, reduced reproductive output and heavier body mass than are found on islands without seabirds.

\section{Methods}

\section{Study area}

Big South Cape Island/Taukihepa (1040 ha, $\left.47^{\circ} 14^{\prime} \mathrm{S}, 169^{\circ} 25^{\prime} \mathrm{E}\right)$, lies c. $2 \mathrm{~km}$ south-west of Stewart Island/Rakiura, New Zealand. It is the largest island in the southern Tìtî Islands; so named because of dense populations of tîtī or sooty shearwaters (Puffinus griseus) breeding over the austral summer and autumn (Newman et al. 2008). Soils are derived from peat and are highly modified in the upper horizons by massive mixing and addition of marine-derived nutrients from the burrowing of tìtī (Hawke \& Newman 2004). The climate is wet (1400 mm annual rainfall), with over 250 rain days $(>0.1 \mathrm{~mm})$ spread throughout the year. The mean annual temperature is $10.3^{\circ} \mathrm{C}$ (Sansom 1984) and strong winds are normal. Research was conducted on four 'manu' or family birding territories: Potted Head on the northwest side of the island; Parakiore on the southern coast; Parata and Manu Maaka Horomanupatu, at Murderers Cove (see Harper 2007; Rutherford et al. 2009).

The low (c. $7 \mathrm{~m}$ ) forest canopy on Big South Cape Island/ Taukihepa is dominated by the tree daisy, tūpare (Oleria colensoi), with occasional rātā (Metrosideros umbellata) and hebe (Hebe elliptica). There are large areas of open ground with deep leaf litter, and some smaller areas of shield fern (Polystichum vestitum), hound's tongue fern (Phymatosorus diversifolius), pūnui (Stilbocarpalyalii), and various Asplenium species. Water fern (Histiopteris incisa) forms dense under canopy breaks. The density of tîti burrows in a 4 ha radiotracking study area (see Rutherford et al. 2009) was 0.504 burrows per $\mathrm{m}^{2}$ (Newman et al. 2008). This reflects the density of burrows found in tūpare forest elsewhere on the island and translates to some 20,160 burrows on the whole island.

\section{Rat capture and tracking}

Live-trapping and radio-tracking were carried out within the tîtī breeding colony at Murderers' Cove. Thirty traps, 15 each of two types of live capture traps, Elliot B (Elliott Scientific Equipment, Upwey, Australia) and 19RT (Pest Management Services Ltd, Waikanae, New Zealand), were deployed $20 \mathrm{~m}$ apart in an $80 \times 100 \mathrm{~m}$ trapping area, within a $200 \times 200 \mathrm{~m}$ sampling grid. Traps were set from 1 to 10 December 2003 and again from 18 to 21 January 2004. Each trap was baited with a peanut butter and rolled oats mix on a carrot disc. Traps were set at dusk (approximately $2120 \mathrm{~h}$ ) and checked hourly until $0200 \mathrm{~h}$. If the weather was cold and wet, traps were then closed to prevent losses due to hypothermia (Daniel 1972). If dry, traps were left open and checked at dawn. All captured rats were anaesthetised with halothane (Veterinary Companies of Australia PTY Ltd, Artarmon, Australia) and sexed and weighed. Approximate reproductive condition was also recorded using external examination of genitals: perforate vagina or descended testes to indicate sexual maturity (Cunningham \& Moors 1996). Any rat exceeding $140 \mathrm{~g}$ had a 4.2 g SIRTRACK (Havelock North, NZ) radio transmitter attached around their neck with a nylon cable-tie, then released. Rats $<140$ g were released without a transmitter, as transmitters weighing $>3 \%$ of body weight have been shown to cause adverse effects on study animals (Kenward 2001).

Radio tagged individuals were located using a TR 4 receiver (Telonics, Mesa, Arizona, United States) and a three element Yagi aerial (Sirtrack Electronics, Havelock North). Attempts to locate each rat were made by approach on foot by a single operator between two to five (normally three) times per night, approximately once an hour. Location data were recorded as coordinates corresponding to the nearest marker point on a $10 \times 10 \mathrm{~m}$ grid square within the sampling grid. Rats were either located visually or detected within one metre with the yagi aerial detached. If rats moved outside the $200 \times 200 \mathrm{~m}$ sampling grid their location was marked with flagging tape. Later the sampling grid was extended to include the location, or the distance to the point outside the grid was measured from a marked grid point to allow the co-ordinates of the position to be calculated. Because rat behaviour could be altered by repetitive disturbance, the order in which rats were located was varied each night to avoid repeatedly entering a rat's home range in the same place, from the same direction or at the same time of night. The previous nights' data were used each night to predetermine the tracking route. This order was maintained throughout the night irrespective of the rat's actual locations during tracking. Moving rats were recorded in the first definite location possible. Daytime sampling also occurred to survey den site selection. The same observer recorded all rat locations.

Observer accuracy was estimated by placing ten transmitters within the study site at positions unknown to the observer. After finding the approximate transmitter location using homing, the observer estimated the distance (in $5 \mathrm{~cm}$ increments) from each transmitter to the nearest grid point, which was compared to an independent person's exact distance to the same grid point.

\section{Home range analysis}

Minimum Convex Polygon(MCP) and kernel density estimates (bivariate normal kernel, with smoothing parameter [h] estimated by least-squares cross validation) of home range size were calculated using a spatial analysis software 'Ranges6' $\mathrm{TM}$. The percentage of home range area used was plotted against the number of locations to create a curve of home range use for each rat and determine whether it reached an asymptote or continued to increase (Harris et al. 1990; Kernohan et al. 2001) Differences in home range area between two periods (December 2004 and January/February 2005) were tested using paired t-tests ( $\alpha=0.05$ assuming unequal variance) as the population density was expected to increase due to breeding activity. Differences in average home range size between male and female used two sample t-tests $(\alpha=0.05)$.

Normality of data used in all t-tests was tested with the Kolmogorov-Smirnov normality test in the computer program SPSS (Version 13.0); t-tests were conducted in MINITAB ${ }^{\circledR}$ (Version 14.1).

\section{Assessment of rat density and productivity}

To estimate rat population density, kill-trapping grids were established on three manu; Potted Head, Parata, and Parakiore (see Harper 2007), in addition to the live-trapping grid at the radio-tracking site. Trapping grids consisted of 81 'Victor'TM snap-traps, in a grid of seven traps at 33-m intervals on 13 alternate offset rows $16 \mathrm{~m}$ apart. The traps were baited with a mixture of rolled oats and peanut butter and secured with wire stakes under $12 \mathrm{~mm}$ galvanised mesh covers. Traps were first set when they were put out and then checked daily for 
the following four to five weeks. Trapping was conducted in December 2003, then in January of 2004 and 2005 and May of 2004 and 2005.

The 'Zippin removal' technique (Zippin 1958) was used to estimate the density of rats caught. Each night's catch was plotted against the cumulative total to estimate the number of rats left on the trapping-grid (see Brown et al. 1996; Harper 2006). To estimate the effective trapping area (ETA), a boundary strip was added to the edge of the trapping grids (Dice 1938). The width of the boundary strip was set by adding the radius of the circular average home range of ship rats recorded by radio-tracking in December and January/February.

Kill-trapped rats were weighed, measured and dissected to determine their age and reproductive state (see Harper 2007 for details). The mean number of embryos per female was used to measure reproductive output. The data gained from the radio-tracking study and trapping grids on Big South Cape Island/Taukihepa were then compared with data from other published research on ship rats in New Zealand.

\section{Results}

\section{Home range estimation}

In December 2003, seven adult females and five adult males were radio-tagged and a further two males in January 2004. No mortality was recorded so all 14 radio-tagged rats were present at the end of the study. All but three of the rats were retrapped at the end of the study. With one exception all females were, or had been, pregnant as determined post mortem by the presence of placental scars.

Home range asymptotes were attained for females $(\sim 30$ locations) and males ( $\sim 40$ locations). Kernel and MCP home ranges were estimated using 1206 night locations along with 15 initial trapping locations, 18 sightings, and 440 daytime locations including den sites. The mean actual distance $(4.38$ $\mathrm{m}$, s.e. \pm 0.33 ) was $6.3 \%$ longer than the mean estimated distance (4.10 $\mathrm{m}, \pm 0.08)$, which was negligible when scaled against home range sizes.

The average $95 \%$ kernel home range estimates for male rats increased from December to January $(0.12$ ha, s.e. \pm 0.02 vs 0.15 ha \pm 0.03 , see Figure 1) but the difference was not significant $(\mathrm{P}=0.115, \mathrm{t}=-2.01, \mathrm{n}=5)$. Female home ranges decreased slightly from December to January $(0.04 \mathrm{ha} \pm 0.01 \mathrm{vs}$ $0.03 \pm 0.01)$ and the difference was not significant $(\mathrm{P}=0.316$, $\mathrm{t}=1.09, \mathrm{n}=7)$. The mean $95 \%$ kernel home range for males was always significantly larger than for females (December $\mathrm{P}=0.007, \mathrm{t}=4.4, \mathrm{n}=5$, Jan/Feb $\mathrm{P}=0.013, \mathrm{t}=3.48, \mathrm{n}=7$ ). MCP plots were always larger for both sexes as the method includes all outliers in the calculation.

Rats were frequently recorded moving through their home range at speeds of $30 \mathrm{~m}$ in 3-4 minutes and also recorded moving long distances over longer periods. For example, M69 moved $107 \mathrm{~m}$ in 66 minutes and M97 moved $78 \mathrm{~m}$ in 32 minutes, which probably underestimate their speed because straight line movements between successive locations were unlikely. Assuming all rats were equally able to traverse their home range, they could reach any part of it within about 10 minutes.

\section{Home range overlap}

Each female was overlapped by an average of 2.3 male home ranges in December, which increased to 3.6 male home ranges in January/February. Each of the five males overlapped an average of three (s.e. \pm 0.32 ) other male home ranges per individual $(\mathrm{HR} / \mathrm{I})$ which increased significantly to $4.5( \pm 0.37)$ in January/February $\mathrm{t}=-3.23, \mathrm{P}=0.01, \mathrm{n}=7$ ). Conversely, female overlap with other female ranges in December did not differ (1.57 HR/I, s.e. $\pm 1.27, \mathrm{n}=7)$ from January/February $(0.57 \pm 0.53 \mathrm{HR} / \mathrm{I}, \mathrm{t}=1.92, \mathrm{P}=0.09, \mathrm{n}=7)$. Many home range overlap areas were very small $(<5 \%)$, and the pattern of home range overlap became clearer if these minor overlaps were ignored. In these cases the number of overlaps was greater within males than females.

\section{Density estimates}

\section{Three kill-trapping grids}

A combined total of 2132 ship rats were trapped over the five trapping sessions on the three trapping grids at Potted Head, Parata and Parakiore. In general rat captures were initially high, but captures declined rapidly from about the fifth day of trapping. Subsequently, most trapped rats were likely

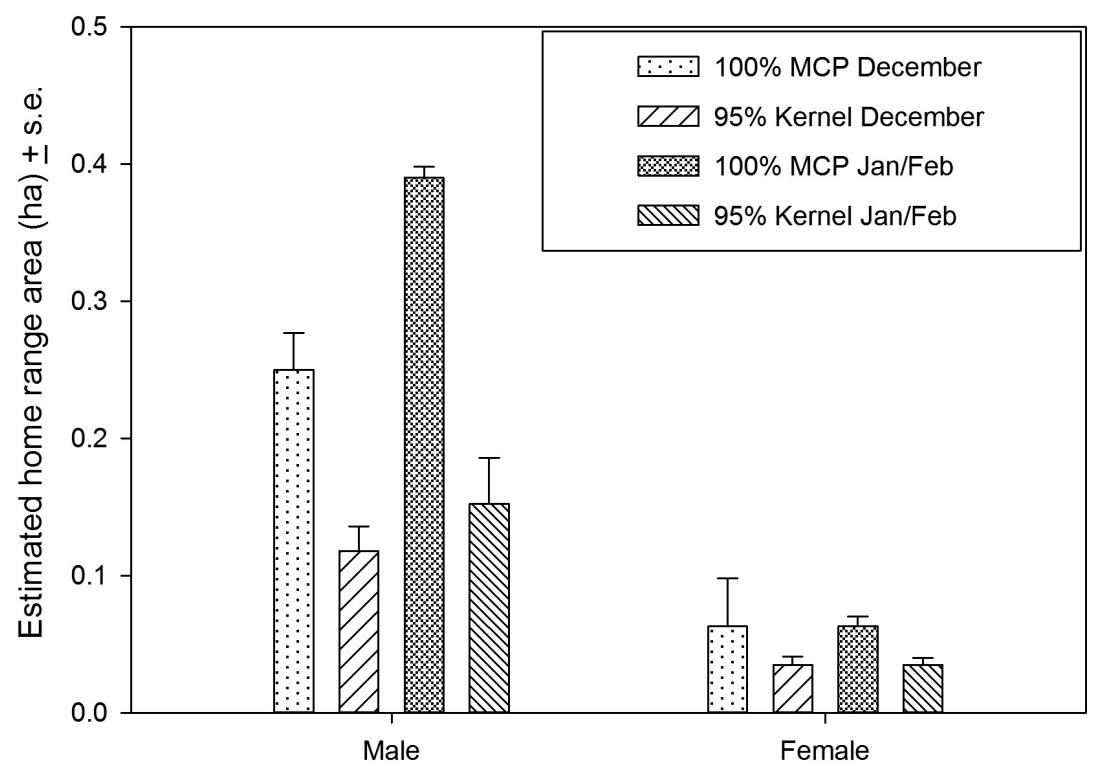

Figure 1. Estimated home range sizes of male and female ship rats on Big South Cape Island/ Taukihepa ( \pm s.e.). 
invading the trapping area from outside the grids. Therefore density estimates were only calculated for the first five days of trapping. The average radius of the radio-tracked male home range area in December gave a boundary strip $28.09 \mathrm{~m}$ wide outside the trapping grid $(80 \mathrm{~m} \times 100 \mathrm{~m})$, which increased to $35.42 \mathrm{~m}$ in January/February. The female boundary strip remained constant at $14.15 \mathrm{~m}$ during both sessions. As no radiotracking was conducted in May the ETA for these trapping sessions were estimated from the home range area recorded over January-February 2004, so it may be underestimated as the capture frequencies were high in May of both years.

The mean density estimate derived from the three grids in December 2003 was 6.52 rats/ha (s.d. 2.86). Mean density densities increased in January 2004 and January 2005 from 10.6-11.6 rats/ha (s.d. $2.71 \& 3.75$ ) to $28.1-36.4$ rats/ha (s.d. $11.06 \& 6.19$ ) in May of both years (Figure 2). During December and January, $45 \%$ of the adult female rats trapped on Big South Cape Island/Taukihepa were pregnant or recently pregnant (Rutherford et al. 2009).

\section{Comparisons with other sites}

Adult ship rats on islands consistently weighed more than rats studied at New Zealand sites (Innes 2005; Latham 2006; Russell et al. 2009; Figure 3, ठ̂: $\mathrm{t}=3.55$, d.f. $=12$, $\mathrm{P}=0.004$; + : Mann-Whitney $\mathrm{U}$ test $=4.0$, d.f. $=12, \mathrm{P}=0.01$ ). These comparisons were calculated from tests on island or site means, not raw data.

Adult female ship rats on islands had significantly more embryos than rats studied at mainland sites $(\mathrm{t}=-3.44$. d.f. $=9$, $\mathrm{P}=0.007$, Table 1$)$. However, only sparse data were available from two of the three islands. These comparisons were calculated from tests on island or site means, not raw data.

There was no significant difference between the mean minimum or maximum recorded population densities on islands and mainland sites (Table 3). The data were log-transformed before analysis (minimum density: $\mathrm{t}=-1.22$, d.f. $=15$, $\mathrm{P}=0.24$; maximum density: $\mathrm{t}=-1.5$, d.f. $=15, \mathrm{P}=0.16$ ).

The plotted mean population density and associated home range sizes of male ship rats in New Zealand are shown in
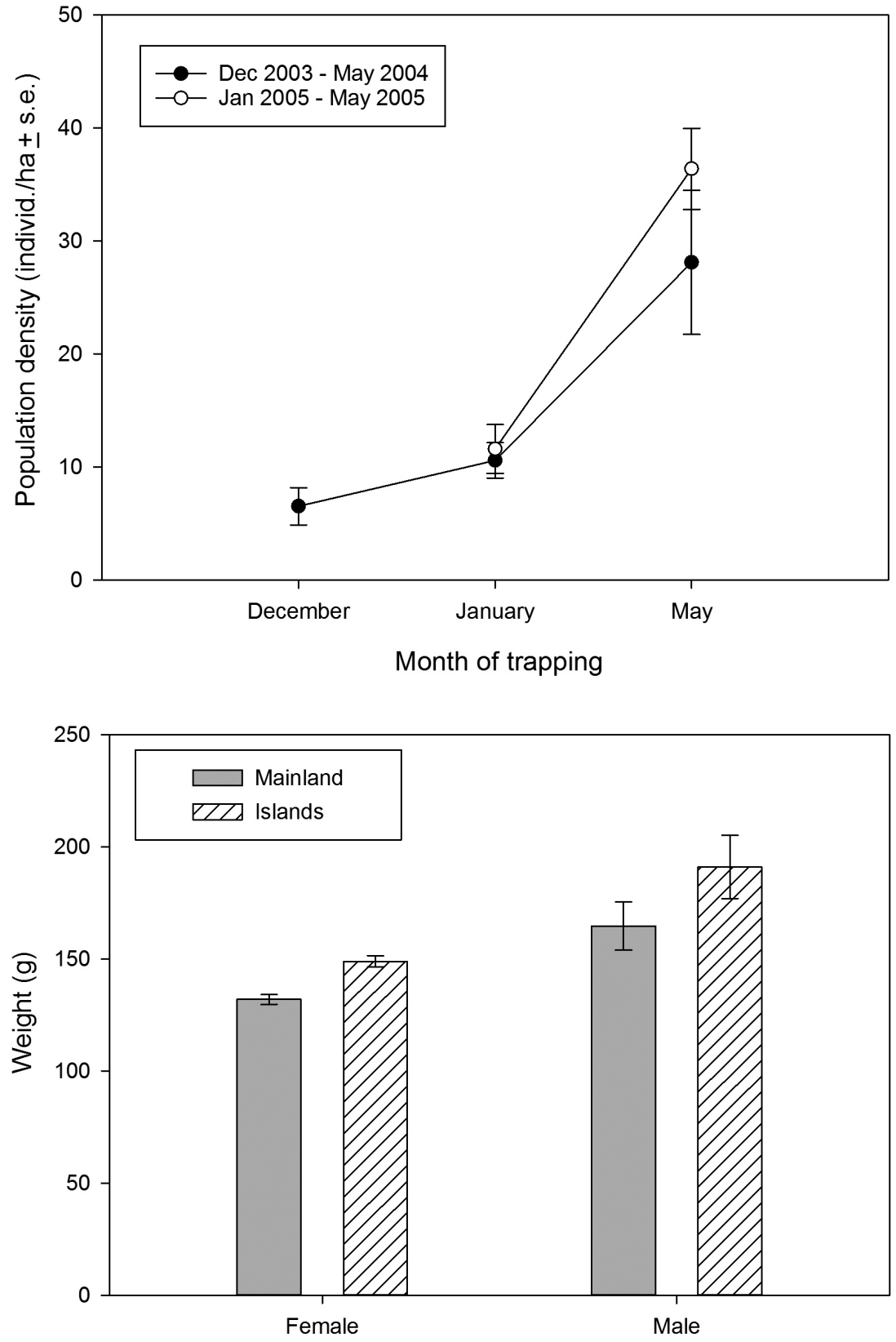

Figure 2. Seasonal changes in estimated mean population densities of ship rats on three trapping grids on Big South Cape Island/Taukihepa.

Figure 3. Mean weights $( \pm$ s.e. $)$ of male and female ship rats from islands $(\mathrm{n}=5)$ and mainland sites $(\mathrm{n}=10)$ in New Zealand. 
Table 1. The mean number of embryos recorded in female ship rats from New Zealand studies.

\begin{tabular}{|c|c|c|c|c|c|}
\hline \multicolumn{3}{|c|}{ Mainland } & \multicolumn{3}{|c|}{ Islands } \\
\hline Author & Location & $\begin{array}{l}\text { Mean no. } \\
\text { of embryos }\end{array}$ & Author & Location & $\begin{array}{l}\text { Mean no. } \\
\text { of embryos }\end{array}$ \\
\hline Innes et al. 1983 & Pureora Forest, Waikato & $5.2(\mathrm{n}=89)$ & $\begin{array}{l}\text { Miller \& Miller } \\
1995\end{array}$ & $\begin{array}{l}\text { Rangitoto } \\
\text { Hauraki Gulf }\end{array}$ & $7.0(\mathrm{n}=2)$ \\
\hline Innes 1979 & North Tararua Range & $4.95(\mathrm{n}=19)$ & $\begin{array}{l}\text { Russell et al. } \\
2009\end{array}$ & $\begin{array}{l}\text { Goat Island } \\
\text { Hauraki Gulf }\end{array}$ & $6.33(\mathrm{n}=3)$ \\
\hline Daniel 1972 & Orongorongo Valley, Wellington & $6.1(n=26)$ & This study & $\begin{array}{l}\text { Taukihepa } \\
\text { Stewart Isld }\end{array}$ & $6.87(\mathrm{n}=209)$ \\
\hline Best 1973 & Banks Peninsula & $5.9(n=14)$ & & & \\
\hline Best 1973 & Waimangaroa, West Coast & $5.9(\mathrm{n}=7)$ & & & \\
\hline King \& Moller 1997 & Hollyford Valley, Fiordland & $5.67(\mathrm{n}=6)$ & & & \\
\hline King \& Moller 1997 & Eglinton Valley, Fiordland & $6.28(\mathrm{n}=7)$ & & & \\
\hline Sturmer 1988 & Robertson River, Stewart Island & $5.86(\mathrm{n}=7)$ & & & \\
\hline Mean & & $\begin{array}{l}5.73 \\
\text { (s.e. 0.16) }\end{array}$ & Mean & & $\begin{array}{l}6.73 \\
\text { (s.e. } 0.21)\end{array}$ \\
\hline
\end{tabular}

Table 2. Ship rat home range estimates (MCP) from New Zealand studies. Note that due to its size, Stewart Island (175,000 ha) is regarded as a mainland site.

\begin{tabular}{|c|c|c|c|c|}
\hline Author & Location & Season & $\begin{array}{c}\text { Average male } \\
\text { home range (ha) } \\
\pm \text { s.e. }\end{array}$ & $\begin{array}{c}\text { Average female } \\
\text { home range (ha) } \\
\pm \text { s.e. }\end{array}$ \\
\hline Daniel $1972^{\mathrm{a}, \mathrm{c}}$ & $\begin{array}{l}\text { Orongorongo Valley } \\
\text { podocarp forest (M) }\end{array}$ & All year & $0.17 \pm 0.28$ & $0.08 \pm 0.06$ \\
\hline $\begin{array}{l}\text { Innes \& Skipworth } \\
1983^{\text {a,c }}\end{array}$ & $\begin{array}{l}\text { Palmerston North } \\
\text { forest remnant }(\mathrm{M})\end{array}$ & May-Jan & 1.01 & $0.33 \pm 0.06$ \\
\hline $\begin{array}{l}\text { Hooker \& Innes } \\
1995^{b, c}\end{array}$ & $\begin{array}{l}\text { Rotoehu } \\
\text { tawa forest (M) }\end{array}$ & Dec-Jan & $1.52 \pm 0.28$ & $0.49 \pm 0.07$ \\
\hline $\begin{array}{l}\text { Dowding \& Murphy } \\
1994^{b, c} \text {. }\end{array}$ & $\begin{array}{l}\text { Northland } \\
\text { kauri forest (M) }\end{array}$ & Sept-Oct & $0.94 \pm 0.23$ & $0.79 \pm 0.07$ \\
\hline $\begin{array}{l}\text { Hickson et al. } \\
1986^{\text {a,c }}\end{array}$ & $\begin{array}{l}\text { Stewart Island } \\
\text { coastal (M) }\end{array}$ & Dec-Feb & \multicolumn{2}{|c|}{$0.54 \pm 0.07$} \\
\hline Pryde et al. $2005^{b, d}$ & $\begin{array}{l}\text { Eglington } \\
\text { beech forest (M) }\end{array}$ & Feb-Mar & 9.43 & 0.27 \\
\hline Latham $2006^{\mathrm{b}, \mathrm{c}}$ & Ponui Island (I) & Dec \& Oct & $0.29 \pm 0.19$ & $0.21 \pm 0.04$ \\
\hline This study $b, c$ & $\begin{array}{l}\text { Taukihepa } \\
\text { coastal tūpare (I) }\end{array}$ & Dec & $0.25 \pm 0.027$ & $0.063 \pm 0.008$ \\
\hline This study ${ }^{b, c}$ & $\begin{array}{l}\text { Taukihepa } \\
\text { coastal tūpare (I) }\end{array}$ & Jan-Feb & $0.40 \pm 0.044$ & $0.063 \pm 0.007$ \\
\hline
\end{tabular}

Notes: a - Home range estimated from trapping and tracking tunnel data - probably underestimate range size.

$\mathrm{b}-$ Home range estimated from radio tracking data.

c $-100 \%$ MCP estimator.

d-95\% MCP estimator used.

M - Mainland site.

I - Island site.

Figure 4. Only two islands, Ponui Island and Big South Cape Island/Taukihepa, had both home range and density data, and in this case the Big South Cape Island/Taukihepa data from December and February are included as the density and home range sizes had changed in the intervening period. Although the data for islands were restricted to two islands the trend in New Zealand was for density to remain consistently low with increasing home range size. On the two islands, the converse appeared to hold, with home ranges remaining consistently small with increasing density.

\section{Discussion}

Home range sizes and population density measurements on Big South Cape Island/Taukihepa were at the extreme ends of the spectrum for ship rats in New Zealand. As expected, home range sizes on Big South Cape Island/Taukihepa were much smaller than all previous home range estimates of ship rats in New Zealand estimated from radio tracking data (Table 2). The estimates from the Orongorongo Valley were close, but were estimated from a trapping grid, a method which underestimates home range size (Ribbell et al. 2002). The key determinants 
Table 3. Population density estimates of ship rats from New Zealand studies.

\begin{tabular}{llll}
\hline Source & Location & Season & $\begin{array}{c}\text { Density estimate } \\
\text { (indiv./ha) }\end{array}$ \\
\hline New Zealand mainland sites & & & \\
\hline Daniel 1972 & Orongorongo Valley, Wellington & Summer & $1.2-3.7$ \\
Daniel 1972 & Orongorongo Valley, Wellington & Autumn & $0.7-2.5$ \\
Hildreth (in Daniel 1972) & Orongorongo Valley, Wellington & Unknown (1951) & $37-49$ (irruption) \\
Hickson et al. 1986 & Stewart Island & Summer & $2.0-2.5$ \\
Dowding \& Murphy 1994 & Northland & Spring & 2.9 \\
Hooker \& Innes 1995 & Rotoehu, Bay of Plenty & Summer & 6.2 \\
Brown et al. 1996 & Kaharoa, Bay of Plenty & Summer & 6.7 (95\% CI: 6.5-7.8) \\
Blackwell et al. 2001 & Lake Waikaremoana, East Coast & Winter & 8.22 \\
Wilson et al. 2007 & Orongorongo Valley, Wellington & Autumn & $4.9-8.7$ \\
Christie et al. 2015 & Eglinton Valley, Fiordland & Spring - Autumn & 0.38 \\
\hline New Zealand islands & & & $12-20$ \\
\hline Craig 1977 & & Autumn & 3.3 \\
Mackay \& Russell 2005 & Goat Island, Hauraki Gulf & Autumn-winter & 2.5 \\
Mackay 2005 & Goat Island, Hauraki Gulf & Autumn & 2.6 \\
Mackay 2005 & Motutapere Island, Coromandel & Autumn & $6.04-10.2$ \\
Shaprio 2005 & Tawhitinui Island, Marlborough Sounds & Summer & $2.09-2.22$ \\
Harper 2006 & Ponui Island, Hauraki Gulf & Autumn & (included 3 Pacific rats) \\
Latham 2006 & Pearl Island, Stewart Island & & $6.73-22.43$ \\
This study & & Winter-Spring & $6.52-36.4$ \\
\hline
\end{tabular}

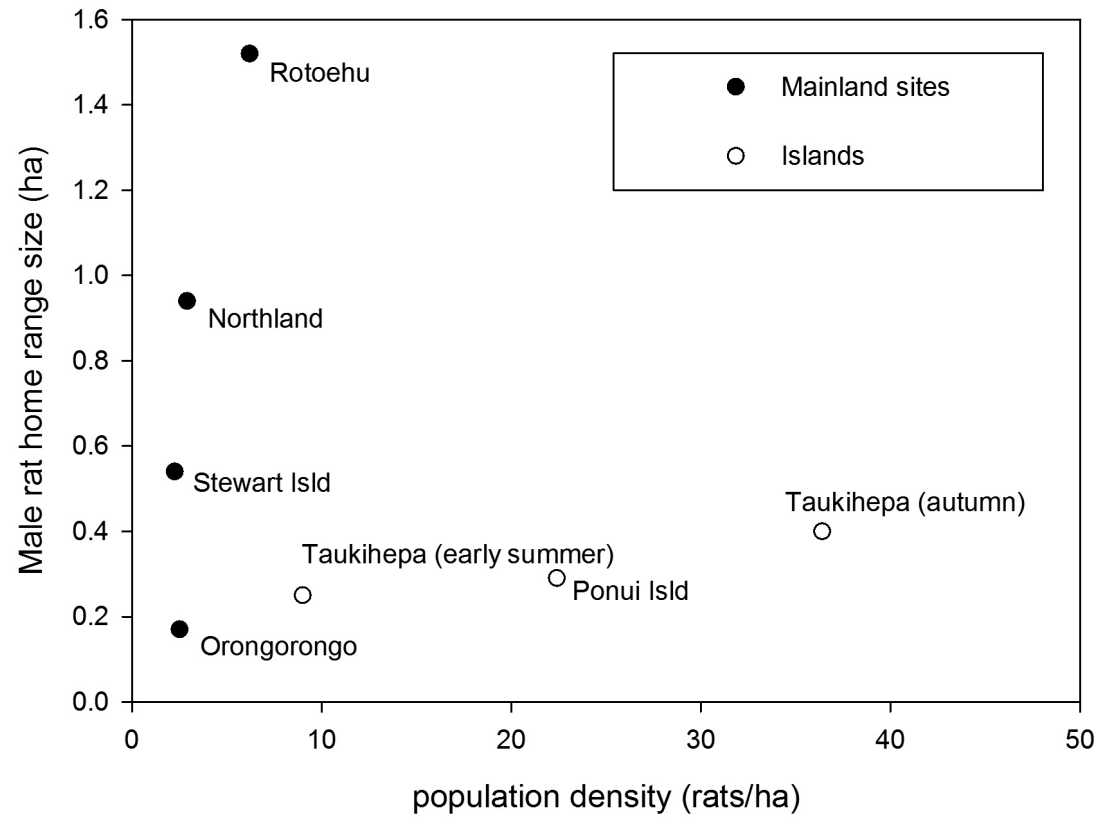

Figure 4. Male home range area and associated population densities of ship rats on islands and mainland sites in New Zealand. of home range size are body mass, individual metabolic rate, ecosystem productivity, and conspecific interactions (McNab 1963; Harestadt \& Bunnel 1979; Russell et al. 2010). As the ship rats on Big South Cape Island/Taukihepa are the largest recorded in New Zealand (Innes 2005), this would suggest they would require a larger home range than usual. The small home range sizes, particularly of females raising young, suggests high primary productivity is the principal driver for the small home range sizes observed. However, there was a repeated decline in population density to lower levels in early summer (Figure 2) which mirrors the usual cessation in breeding over winter in New Zealand rat populations (Harper et al. 2005). This suggests an interaction of density with restricted resources through the winter, possibly related to the departure of sooty shearwaters in autumn.

The very high density population estimates from Big South Cape Island/Taukihepa support this conclusion. The measured peak densities are the highest so far recorded in New Zealand, in many cases by an order of magnitude, and have only been approached on the mainland during an apparent population irruption (Table 3). The only other site where population 
densities near to those measured were recorded was at Ponui Island in the Hauraki Gulf(Latham 2006). The high densities, along with the small observed home ranges, suggests that there are fundamental differences in ecosystem function between Big South Cape Island/Taukihepa and other sites where population density has been measured. The contrast could not be greater than at nearby Pearl Island, only $20 \mathrm{~km}$ away, which had very similar climatic and edaphic conditions, a lack of predators and three competing rat species, but very few or no breeding seabirds. Fewer than three rats per hectare were measured there using the same technique at a similar time of year (Harper 2006). The rat population density measured on Pearl Island is very similar to densities recorded by Hickson et al. (1986) further north on Stewart Island (Table 3), where competitors and also predators are present. The relatively high rat densities seen on Ponui Island and Goat Island in the Hauraki Gulf may reflect a high background level of soil fertility (Gardner-Gee \& Beggs 2009), which may be due to now absent or sparse seabird colonies or soils with generally higher fertility than exists in the peat soils of Big South Cape Island/Taukihepa. In this case the contrasting effect of seabird marine subsidies on rat densities on Big South Cape Island/ Taukihepa versus Pearl Island is probably due to the large size of the subsidy relative to the base productivity of the cool, wet habitats present at Stewart Island (Marczak et al. 2007; Mulder et al. 2011; Bassett et al. 2014).

Similarly high population densities and adult body mass in ship rats have been found on dry Mediterranean Islands where seabirds are present and following heavy rainfall (Ruffino et al. 2009; Ruffino et al. 2013). Notably heavier ship rats have also been trapped within seabird colonies on tropical islands (Tetiaroa, French Polynesia, Russell et al. 2011a; Great Tobago Island, British Virgin islands, GH pers. obs.), and higher ship rat population densities are found in the tropics (Russell et al. 2011b; Harper et al. 2015), where primary productivity is greater (Melillo et al. 1993; Schurr 2003; Gillman et al. 2015). This suggests higher productivity is the principal driver for the small home range sizes and high rat densities observed on Big South Cape Island/Taukihepa. This mirrors the results from the Shiant Islands, Scotland, where ship rats were in higher densities (22-85 rats/ha) and heavier on the island with a large puffin colony, in contrast to rats trapped on the immediately adjacent island without seabirds (Key et al. 1998). Similarly, very heavy ship rats (mean adult weight: $246 \mathrm{~g}$ ) were trapped in white-chinned petrel Procellaria aequinoctialis colonies on Ile de Possession, southern Indian Ocean (Jouventin et al. 2003).

In lieu of solar input to drive primary productivity as occurs in the tropics, marine inputs via nesting seabirds can massively increase productivity on temperate islands (Polis $\&$ Hurd 1996). Concentrations of nutrients such as nitrogen, phosphorous and potassium can be $18 \mathrm{x}$ greater on seabird islands (Wolfe et al. 2004) which can lead to increased plant growth (Molina-Montenegro etal. 2013). Much higher densities of arthropods (Sánchez-Piñero \& Polis 2000), consumers like lizards (Barrett et al. 2005) and rodents (Stapp \& Polis 2003), and predators (Rose \& Polis 1998) have also been measured. Although the densities of invertebrates have not been recorded on Big South Cape Island/Taukihepa, they are also likely to be much higher than on non-seabird islands in New Zealand (Markwell \& Daugherty 2002) which suggests a role for increased available food on Big South Cape Island/Taukihepa leading to the densities of rats observed. Indeed island rodent population densities will increase when experimentally supplemented with food, in contrast to control populations
(Adler 1998). Certainly the rats on Big South Cape Island/ Taukihepa have a high quality, protein rich diet, comprising mainly invertebrates and birds (Harper 2006). Rodent diet does tend to have more invertebrates at higher latitude islands like Big South Cape Island/Taukihepa (St Clair 2011), but the larger proportion of bird remains in their diet contrasts with most observed prey items of New Zealand ship rats which are dominated by plant material and invertebrates (Innes 2005). A high protein diet may also result in the observed large litter sizes (Widdowson \& Cowen 1972) leading to increased population densities (Adler 1998).

The contention that the diet of rats on Big South Cape Island/Taukihepa is marine subsidised relative to Pearl Island is supported by stable isotope data from rat muscle from these sites (Harper 2006, 2007). The ship rats on Big South Cape Island/ Taukihepa had highly enriched stable-nitrogen isotope $\left(\delta^{15} \mathrm{~N}\right)$ values of 14.66 (s.e. 0.58 ), which were strongly suggestive of a marine subsidised component in their diet (Stapp 2002), whereas ship rats in forest on Pearl Island had $\delta^{15} \mathrm{~N}$ values of 4.07 (s.e. 1.02). Ship rats trapped on the shoreline at Pearl Island had $\delta^{15} \mathrm{~N}$ values of 12.97 (s.e. 0.98), which were similar to Big South Cape Island/Taukihepa values, as rats foraging in the littoral zone can have enriched $\delta^{15} \mathrm{~N}$ values due to the preponderance of intertidal invertebrate as prey (Stapp 2002). The values on Pearl Island forest were higher still than that recorded in similar forest at the Rakeahua Valley, in central Stewart Island, where ship rats had $\delta^{15} \mathrm{~N}$ values of only 2.0 (s.e. 0.23, Harper 2006), reflecting its distance from the sea. A similar response by ship rats to the presence of seabirds has been recorded on the Shiant Islands (Scotland) and Bagaud Island (Mediterranean) where rats resident in seabird colonies had highly enriched $\delta^{15} \mathrm{~N}$ values of 17.1 and $\sim 13$ respectively (Stapp 2002; Ruffino et al. 2011).

In regard to the 'island syndrome' in New Zealand the data were equivocal. Ship rats on islands were heavier and larger (Yom-tov et al. 1999) than on mainland New Zealand which supports the micro-evolutionary portion of the theory, probably because a large suite of competitors and predators were absent (Adler \& Levins 1994; Yom-tov et al. 1999; Ventura \& Lopez Fuster 2000). Rapid morphological responses in rodents and other small mammals to changing ecological conditions are now well recorded (Pergams \& Ashley 2001; Pergams \& Lawyer 2009; Cucchi et al. 2014). At an ecological level however, results were less clear. For example, female rats produced more embryos on islands than on mainland New Zealand, and mean population densities were not significantly different between mainland New Zealand and the island sites, despite the highest population densities attained on Big South Cape Island/Taukihepa. On all islands except Goat Island, dispersal for the sampled islands could be regarded as nil, so the driving forces for likely responses were present. Unfortunately some of the data from islands were sparse which restricts us from coming to a firm conclusion as to the relevance of the 'island syndrome' theory in the New Zealand context but may suggest a gradient of behavioural and population responses with increasing island size. Comparisons between marine subsidised rat populations on islands and at mainland sites with seabird colonies may tease out the relative effects of seabird-driven productivity versus the island syndrome. The paucity of home range data from New Zealand islands also affected a comparison of home range with population density, but differences in the response of ship rats to the prevailing ecological conditions on the mainland and the two islands was apparent (Figure 4). On the two islands, Ponui and Big 
South Cape Island/Taukihepa, home range size remained relatively constant with high population densities. This lack of response to increasing density has also been observed in Pacific rats on Kure Atoll (Wirtz 1972), where high densities are attained, and competitors and predators were absent. In contrast, at mainland New Zealand sites home range sizes were generally larger relative to the islands, and observed home ranges fluctuated about consistently low population densities. This observation may provide a useful modification of the 'island syndrome', where the relationship between home range and density (Efford et al. 2015) is one of the defining differences on islands rather than population density per se. Further research is required to confirm this interim result and its relevance to the 'island syndrome', and the relative effects of predators and competitors on the ecological and evolutionary response of invasive rats. What is clear is that the ship rats of Big South Cape Island/Taukihepa have specifically responded at both a micro-evolutionary and population ecology level to the prevailing conditions.

\section{Acknowledgements}

This work is a contribution from the Kia Mau Te Tìtī Mo Ake Tōnu Atu (Keep the Tìtî Forever) Research Project, funded by the Foundation for Research, Science \& Technology through a Post-Doctoral Fellowship (UOOX0232), a Public Good Research Fund grant (RTIX0301), the Command Oil Damage Restoration fund, through Oikonos (USA), the Ka Mate Nga Kiore committee and the Zoology Department, Otago University. The Rakiura Tìtî Islands committee and Rakiura Tītī Island Administering Body provided permission and guidance through the research. Many thanks to the volunteers from the Rakiura mutton-birding community and elsewhere who assisted and to the many island manu owners who permitted access and often assistance. Ron Bull deserves special thanks for allowing us to use his whare. South West Helicopters assisted with transport. The staff of the Kia Mau Te Titi Mo Ake Tonu (Keep the Titi Forever) research project were particularly helpful and great company. Many staff of the Zoology Department, University of Otago, also assisted. This research was carried out under the University of Otago ethics approvals $102 / 02$ and $85 / 04$. We wish to thank the two reviewers and James Russell for comments which substantially improved the paper.

\section{References}

Adler GH 1998. Impacts of resource abundance on populations of a tropical forest rodent. Ecology 79: 242-254.

Adler GH, Levins R 1994. The island syndrome in rodent populations. The Quarterly Review of Biology 69: 473-490.

Atkinson IAE1978. Evidence for effects of rodents on the vertebrate wildlife of New Zealand islands. In: Dingwall PR, Atkinson IAE, Hay C eds The ecology and control of rodents in New Zealand nature reserves. Information Series No 4. Wellington, New Zealand, Department of Lands and Survey Information. Pp. 7-33.

BarrettK, Anderson WB, WaitDA, Grismer LL, Polis GA, Rose MD 2005. Marine subsidies alter the diet and abundance of insular and coastal lizard populations. Oikos 109: 145-153.

Bassett IE, Elliott GP, Walker KJ, Thorpe S, Beggs JR 2014.
Are nesting seabirds important determinants of invertebrate community composition on subantarctic Adams Island? Polar Biology 37: 531-540.

Bell BD 1978. The Big South Cape Islands rat irruption. In: Dingwall PR, Atkinson IAE, Hay C eds The ecology and control of rodents in New Zealand nature reserves. Information Series No 4. Wellington, New Zealand, Department of Lands and Survey Information. Pp. 33-40.

Bell EA, Bell BD, Merton DV 2016. The legacy of Big South Cape: rat irruption to rat eradication. New Zealand Journal of Ecology 40: 212-218.

Best LW 1973. Breeding season and fertility of the roof rat, Rattus rattus rattus, in two forest areas of New Zealand. New Zealand Journal of Science 16: 161-170.

Brown KP, Moller H, Innes J, Alterio N 1996. Calibration of tracking tunnel rats to estimate relative abundance of ship rats (Rattus rattus) and mice (Mus musculus) in a New Zealand forest. New Zealand Journal of Ecology 20: 271-275.

Christie JE, MacKenzie DI, Greene TC, Sim JL 2015. Using passive detection devices to monitor occupancy of ship rats (Rattus rattus) in New Zealand temperate rainforest New Zealand Journal of Ecology 39: 79-86.

Courchamp F, Chapuis J, Pascal M 2003. Mammal invaders on islands: impact, control and control impact. Biological Reviews 78: 347-383.

Craig JL 1977. The rats on Goat Island and their effects on the vegetation. Report to Hauraki Gulf Maritime Park Board. Auckland, New Zealand, University of Auckland.

Cucchi T, Barnett R, Mart'inkova' N, Renaud S, Renvoise E, Evin A, Sheridan A, Mainland I, Wickham-Jones C, Tougard C, Quéré JP, Pascal M, Pascal M, Heckel G, O’Higgins P, Searle JB, Dobney KM 2014. The changing pace of insular life: 5000 years of microevolution in the Orkney vole (Microtus arvalis orcadensis). Evolution 68: 2804-2820.

Cunningham DM, Moors PJ 1996. Guide to the identification and collection of New Zealand rodents. Wellington, New Zealand, Department of Conservation. 24 p.

Daniel MJ 1972. Bionomics of the ship rat (Rattus r. rattus) in a New Zealand indigenous forest. New Zealand Journal of Science 15: 313-341.

Dice LR 1938. Some census methods for mammals. Journal of wildlife management 2: 119-130.

Dowding JE, Murphy EC 1994. Ecology of ship rats (Rattus rattus) in a kauri (Agathis australis) forest in Northland, New Zealand. NZ Journal of Ecology 18: 19-28.

Efford MG, Dawson DK, Jhala YV, Qureshi Q 2015. Densitydependent home-range size revealed by spatially explicit capture-recapture. Ecography: in press.

Fukami T, Wardle DA, Bellingham PJ, Mulder CPH, Towns DR, Yeates GW, Bonner KI, Durrett MS, Grant-Hoffman MN, Williamson WM 2006. Above- and below-ground impacts of introduced predators in seabird-dominated island ecosystems. Ecology Letters 9: 1299-1307.

Gardner-GeeR, Beggs JR 2009. Does the presence of burrowing seabirds increase local invertebrate abundance? New Zealand Entomologist 32: 41-47.

Gillman LN, Wright SD, Cusens J, McBride PD, Malhi Y, Whittaker RJ 2015. Latitude, productivity and species richness. Global Ecology and Biogeography 24: 107-117.

Gliwicz J 1980. Island populations of rodents: their organization and functioning. Biological Review 55: 109-138.

Harestad AS, Bunnell FL 1979. Home range and body weight 
- a re-evaluation. Ecology 60: 389-402.

Harper GA 2006. Habitat use by three rat species (Rattus spp.) on an island without other mammalian predators. New Zealand Journal of Ecology 30: 321-333.

Harper GA 2007. Detecting predation of a burrow-nesting seabird by two introduced predators, using stable isotopes, dietary analysis and experimental removals. Wildlife Research 34: 443-453.

Harper GA, Dickinson KJM, Seddon PJ 2005. Habitat use by three rat species (Rattus spp.) on Stewart Island/ Rakiura, New Zealand. New Zealand Journal of Ecology 29: 251-260.

Harper GA, van Dinther M, Russell JC, Bunbury N 2015. The response of black rats (Rattus rattus) to evergreen and seasonally arid habitats: informing eradication planning on a tropical island. Biological Conservation 185: 66-74.

Harris SWJ, Cresswell PG, Forde WJ, Trewhella T, Woodlard T, Wray S 1990. Home-range analysis using radio-tracking data - a review of problems and techniques particularly as applied to the study of mammals. Mammal Review 20: $97-123$.

Hawke DJ, Newman J 2004. Inventories and elemental accumulation in peat soils of forested breeding islands, southern New Zealand. Australian Journal of Soil Research 42: 45-48.

Hickson RE, Moller H, Garrick AS 1986. Poisoning rats on Stewart Island. New Zealand Journal of Ecology 9: 111-121.

Hooker S, Innes J 1995. Ranging behaviour of forestdwelling ship rats, Rattus rattus, and effects of poison with brodifacoum. New Zealand Journal of Zoology 22: 291-304.

Innes JG 1979. Diet and reproduction of ship rats in the northern Tararuas. New Zealand Journal of Ecology 2: 85-86.

Innes JG 2005. Ship rat. In: King CM ed The handbook of New Zealand mammals. $2^{\text {nd }}$ ed. Melbourne, Oxford University Press. Pp. 56-80.

Innes JG, Skipworth JP 1983. Home range of ship rats in a small New Zealand forest as revealed by trapping and tracking. NZ Journal of Ecology 10: 99-110.

Innes JG, King CM, Flux M, Kimberley MO 2001. Population biology of the ship rat and Norway rat in Pureora Forest Park, 1983-87. New Zealand Journal of Zoology 28: 57-78.

Jones HP, Tershy BR, Zavaleta ES, Croll DA, Keitt BS, Finkelstein ME, Howald GR 2008. Severity of the effects of invasive rats on seabirds: A global review. Conservation Biology 22: 16-26.

Jouventin P, Bried J, Micol T 2003. Insular bird populations can be saved from rats: a long-term experimental study of white-chinned petrels Procellaria aequinoctialis on Ile de la Possession (Crozet archipelago). Polar Biology 26: $371-376$.

Kenward RE 2001. A Manual for Wildlife Radio Tagging. London, Academic Press. 311 p.

Kernohan BJ, Gitzen RA, Millspaugh JJ 2001. Analysis of animal space use and movements. In: Millspaugh JJ, Marzluff LM eds Radio tracking and animal populations. San Diego, USA, Academic Press. Pp. 125-166.

Key GE, Fielding AH, Goulding MJ, Holm RS, Stevens-Woods B 1998. Ship rats (Rattus rattus) on the Shiant Islands, Hebrides, Scotland. Journal of Zoology 245: 228-233.

King CM, Moller H 1997. Distribution and response of rats Rattus rattus, R.exulans to seedfall in New Zealand beech forests. Pacific Conservation Biology 3: 143-155.

Latham JE 2006. The ecology of ship rats (Rattus rattus) on Ponui Island: implications for North Island brown kiwi (Apteryx mantelli). MSc thesis. Auckland, New Zealand, University of Auckland. $127 \mathrm{p}$.

MacKay JWB 2005. The population biology of Rattus rattus on three recently reinvaded New Zealand islands. Unpublished MSc thesis. Norwich, UK, University of East Anglia.

MacKay JWB, Russell JC 2005. Eradication of ship rats from Goat Island April-October 2005. Unpublished report to the Department of Conservation. University of Auckland. $13 \mathrm{p}$.

McNab BK 1963. Bioenergetics and the determination of home range size. American Naturalist 47:133-140.

Marczak LB, Thompson RM, Richardson JS 2007. Metaanalysis: trophic level, habitat, and productivity shape the food web effects of resource subsidies. Ecology 88: $140-148$.

Markwell TJ, Daugherty CH 2002. Invertebrate and lizard abundance is greater on seabird inhabited islands than on seabird-free islands in the Marlborough Sounds, New Zealand. Ecoscience 9: 293-299.

Melillo JM, Mcguire AD, Kicklighter DW, Moore B, Vorosmarty CJ, Schloss AL 1993. Global climate change and terrestrial net primary production. Nature 363: 234-240.

Miller CJ, Miller TK 1995. Population dynamics and diet of rodents on Rangitoto Island, New Zealand, including the effect of a 1080 poison operation. New Zealand Journal of Ecology 19: 19-27.

Molina-Montenegro MA, Torres-Díaz, Gallardo-Cerda J, Leppe M, Gianoli E 2013. Seabirds modify El Niño effects on tree growth in a southern Pacific island. Ecology 94: 2415-2425.

Mulder CP, Grant-Hoffman MN, Towns DR, Bellingham PJ, Wardle DA, Durrett MS, Fukami T, Bonner KI 2009. Direct and indirect effects of rats: does rat eradication restore ecosystem functioning of New Zealand seabird islands? Biological Invasions 11: 1671-1688.

Mulder CHP, Anderson WB, Towns DR, Bellingham PJ 2011. Seabird islands: ecology, invasion, and restoration. New York, Oxford University Press. 512 p.

Newman J, Scott D, Fletcher D, Moller H, McKechnie S 2008. A population and harvest intensity estimate for sooty shearwater (Puffinus griseus) on Taukihepa (Big South Cape), New Zealand. Papers and Proceedings of the Royal Society of Tasmania 142: 177-184.

Pergams ORW, Ashley MV 2001. Microevolution in island rodents. Genetica 112: 245-256.

Pergams ORW, Lawler JJ 2009. Recent and widespread rapid morphological change in rodents. PloS ONE 4: e6452.

Polis GA, Hurd SD 1996. Linking marine and terrestrial food webs: allochthonous input from the ocean supports high secondary productivity on small islands and coastal land communities. American Naturalist 147: 396-423.

Polis GA, Anderson WB, Holt RD 1997. Toward an integration of landscape and food web ecology: the dynamics of spatially subsidized food webs. Annual Review of Ecology and Systematics 28: 289-316.

Pryde M, Dilks P, Fraser I 2005. The home range of ship rats (Rattus rattus) in beech forest in the Eglinton Valley, Fiordland, New Zealand: A pilot study. New Zealand Journal of Zoology 32: 139-142.

Ramsay GW 1978. Areview of the effect of rodents on the New 
Zealand invertebrate fauna. In: Dingwall PR, Atkinson IAE, Hay $\mathrm{C}$ eds The ecology and control of rodents in New Zealand nature reserves. Information Series No 4. Wellington, New Zealand, Department of Lands and Survey. Pp. 89-95.

Ribble DO, Wurtz AE, McConnell EK, Buegge JJ, Welch KC 2002. A comparison of home ranges of two species of Peromyscus using trapping and radiotelemetry data. Journal of Mammalogy 83: 260-266.

Rose MD, Polis GA 1998. The distribution and abundance of coyotes: the effects of allochthonous food subsidies from the sea. Ecology 79: 998-1007.

Ruffino L, Bourgeois K, Vidal E, Duhem C, Paracuellos M, Escribano F, Sposimo P, Baccetti N, Pascal M, Oro D 2009. Invasive rats and seabirds after 2,000 years of an unwanted coexistence on Mediterranean islands. Biological Invasions 11: 1631-1651.

Ruffino L, Russell JC, Pisanu B, Caut S, Vidal E 2011. Low individual-level dietary plasticity in an island-invasive generalist forager. Population Ecology 53: 535-548.

Ruffino L, Russell JC, Vidal E 2013. Anthropogenic subsidies mitigate environmental variability for insular rodents. Oecologia 172: 737-749.

Russell JC, Mackay JWB, Abdelkrim J 2009. Insular pest control within a metapopulation context. Biological Conservation 142: 1404-1410.

Russell JC, McMorland AJC, Mackay JWB 2010. Exploratory behaviour of colonizing rats in novel environments. Animal Behaviour 79: 159-164.

Russell JC, Faulquier L, Tonione MA 2011a. Rat invasion of Tetiaroa atoll, French Polynesia. In: Veitch CR, Clout MN, Towns DR eds Island invasives: eradication and management. Gland, Switzerland and Auckland New Zealand, IUCN. Pp. 118-123.

Russell JC, Ringler D, Trombini A, Le Corre M 2011b. The island syndrome and population dynamics of introduced rats. Oecologia 167: 667-676.

Rutherford M, Harper GA, Moller H 2009. Denning behaviour of ship rats (Rattus rattus) on Taukihepa, a seabird breeding island. New Zealand Journal of Zoology 36: 343-353.

St Clair JHH 2011. The impacts of invasive rodents on island invertebrates. Biological Conservation 144: 68-81.

Sánchez-Piñero F, Polis GA 2000. Bottom-up dynamics of allochthonous input: direct and indirect effects of seabirds on islands. Ecology 81: 3117-3132.

Sansom J 1984. The climate and weather of Southland. Publication No. 115 (15). Wellington, New Zealand Meteorological Service. 50 p.
Schurr EAG 2003. Productivity and global climate revisited: the sensitivity of tropical forest growth to precipitation. Ecology 84: 1165-1170.

Shapiro LM 2005. Diet overlap and potential competition between North Island brown kiwi chicks (Apteryx mantelli) and ship rats (Rattus rattus) for limited resources on Ponui Island, New Zealand. Unpublished MSc thesis. Palmerston North, New Zealand, Massey University. 252 p.

Stapp P 2002. Stable isotopes reveal evidence of predation by ship rats on seabirds on the Shiant Islands, Scotland. Journal of Applied Ecology 39: 831-840.

Stapp P, Polis GA 2003. Marine resources subsidize insular rodent populations in the Gulf of California, Mexico. Oecologia 134: 496-504.

Sturmer AT 1988. Diet and coexistence of Rattus rattus rattus (Linnaeus), Rattus exulans (Peale) and Rattus norvegicus (Berkenhout) on Stewart Island. MSc thesis. Palmerston North, New Zealand, Massey University. 128 p.

Towns DR, Wardle DA, Mulder CPH, Yeates GW, Fitzgerald BM, Parrish GR, Bellingham PJ, Bonner KI 2009. Predation of seabirds by invasive rats: multiple indirect consequences for invertebrate communities. Oikos 118: 420-430.

Ventura J,López-Fuster MJ 2000. Morphometric analysis of the black rat Rattus rattus, from Congreso Island (Chararinas Archipelago, Spain). Orsis 15: 91-102.

Wardle DA, Bellingham PJ, Fukami T, Mulder CPH 2007. Promotion of ecosystem carbon sequestration by invasive predators. Biology Letters 3: 479-482.

Widdowson EM, Cowan J 1972. The effect of protein deficiency and calorie deficiency on the reproduction of rats. British Journal of Nutrition 27: 85-95.

Wilson DJ, Efford MG, Brown SJ, Williamson JF McElrea GJ 2007. Estimating density of ship rats in New Zealand forests by capture mark-recapture trapping. New Zealand Journal of Ecology 31: 47-59.

Wirtz WO 1972. Population ecology of the Polynesian rat on Kure Atoll, Hawaii. Pacific Science 26: 433-464.

Wolfe KM, Mills HR, Garkaklis MJ, Bencini R 2004. Postmating survival in a small marsupial is associated with nutrient inputs from seabirds. Ecology 85: 1740-1746.

Yom-Tov Y, Yom-Tov S, Moller H 1999. Competition, coexistence, and adaptation amongst rodent invaders to Pacific and New Zealand islands. Journal of Biogeography 26: 947-958.

Zippin C 1958. The removal method of population estimation. Journal of Wildlife Management 22: 82-90. 